\title{
PENGEMBANGAN MODUL MATEMATIKA BERBASIS REALISTIK TERINTEGRASI HIGHER ORDER THINKING SKILLS (HOTS) PADA MATERI BANGUN RUANG
}

\author{
Achmad Chuseri $^{1 *}$ (D) Titi Anjarini $^{2}$ iD, Riawan Yudi Purwoko 3 i \\ Universitas Muhammadiyah Purworejo, Indonesia \\ 1*achmadchuseri@gmail.com, ${ }^{2}$ anjarini@umpwr.ac.id, ${ }^{3}$ riawanyudi@umpwr.ac.id
}

\begin{abstract}
:
Learning media is an important tool in learning proces, especially learning media that are made based on student needs and characteristics. One of learning media that is effectively applied at the primary school level is a module. This study aims to produce and determine the feasibility of mathematics learning media in the form of HOTS integrated realistic-based modules on volume building materials (cubes and blocks) as learning media for fifth grade elementary school students. The subjects of study were six students of grade V SD Negeri Sindurjan. The research method was used R\&D (Research and Development) using ADDIE model. The ADDIE model consists of analysis, design, development, implementation, evaluation. Based on the results of research (1), a HOTS integrated realistic mathematics module development product is produced. (2) The validation results obtained from the evaluation of media experts by 3.20 and material experts by 3.65. From the two results, it was developed to be 3.40 or $>3.25$, the very valid category. (3) The practicality questionnaire was obtained from the student response assessment of 3.40 or $>3.25$ with the very practical category. Thus the HOTS integrated realistic-based mathematics module is suitable for use as a learning medium for fifth grade elementary school students.
\end{abstract}

Keywords: HOTS, Mathematics, Module, Realistic.

How to Cite: Chuseri, A., Anjarini, T., \& Purwoko, R. Y. (2021). Pengembangan Modul Matematika Berbasis Realistik Terintegrasi Higher Order Thinking Skills (HOTS) pada Materi Bangun Ruang. Alifmatika: Jurnal Pendidikan dan Pembelajaran Matematika, 3(1), 18-31. https://doi.org/10.35316/alifmatika.2021.v3i1.18-31

\section{PENDAHULUAN}

Menurut Depdiknas “Dalam UU No. 20 Tahun 2003 tentang Sisdiknas Pasal 1 Ayat 20, pembelajaran merupakan proses interaksi antara siswa dengan pendidik dan sumber belajar pada suatu lingkungan belajar" (Widyautama, 2003). Pembelajaran di era sekarang ini tidak lagi memandang siswa sebagai gelas kosong, artinya siswa tidak hanya dituntut untuk memenuhi kewajiban pengajaran, tetapi belajar merupakan kegiatan yang dilakukan seseorang agar dapat mencapai kompetensi yang diinginkan. Rahayu \& Firmansyah (2019: 21) juga mengemukakan bahwa pembelajaran merupakan proses interaksi antara siswa dengan lingkungannya, yang semula tidak bisa menjadi bisa setelah dilakukan pengajaran. Beberapa pendapat para ahli tersebut dapat disimpulkan bahwa sebuah pembelajaran memerlukan suatu interaksi aktif antara guru yang memberikan bahan pelajaran dengan siswa sebagai objeknya, harapannya agar 
siswa dapat merubah perilakunya menjadi lebih baik. Pembentukan interaksi yang aktif antara guru dengan siswa dapat dilakukan dengan menggunakan media pembelajaran berupa alat peraga, sumber buku, modul ataupun lainnya yang sekiranya dapat menunjang kegiatan pembelajaran. Seperti yang diutarakan oleh Rusmana \& Kurniawarsih (2020: 40) bahwa media pembelajaran merupakan sebuah alat peraga yang digunakan untuk mempermudah siswa dalam mempelajari hal yang abstrak melalui perantara benda konkret. Sedangkan media pembelajaran menurut Ramadani \& Oktiningrum (2020) mengatakan bahwa suatu alat bantu/instrumen yang digunakan sebagai perantara untuk menyampaikan pesan atau materi pembelajaran kepada siswa agar lebih mudah dimengerti. Berdasarkan beberapa pendapat di atas, dapat disimpulkan bahwa media pembelajaran merupakan segala bentuk bahan, alat, atau segala sumber daya yang digunakan guru untuk menyampaikan materi guna membantu merangsang pikiran dan kemampuan siswa dalam proses belajar mengajar. Media pembelajaran juga berperan dalam menentukan kualitas belajar siswa guna mempermudah mereka memamahami materi yang disampaikan. Namun kenyataan yang ada, media pembelajaran yang digunakan belum mampu membuat siswa untuk berpikir realistik.

Berdasarkan observasi yang ditemukan di lapangan, salah satu faktor yang menyebabkan rendahnya kualitas belajar siswa yaitu sebagian besar guru mendominasi, sedangkan siswa menjadi pendengar yang pasif. Hal ini bisa terjadi dikarenakan siswa hanya digunakan sebagai subjek guru dalam penyampaian materi. Kegiatan yang mampu menunjang siswa dalam mengembangkan kemampuan berpikir logisnya membutuhkan media pembelajaran yang berkualitas berupa modul. Menurut Rokhim, Suparmi, \& Prayitno (2018) modul merupakan media pembelajaran yang disusun secara sistematis dengan bahasa yang mudah dipahami sesuai dengan tingkat usia siswa. Melalui modul diharapkan penggunaannya dapat membiasakan siswa agar belajar mandiri dengan atau tanpa bimbingan guru. Sebagaimana dijelaskan oleh Istikomah \& Purwoko (2020: 64) bahwa modul disusun secara runtut dan dapat dipelajari secara mandiri sehingga dapat berdampak positif terhadap hasil belajar siswa. Secara garis besar modul dapat dikatakan sebagai satu unit bahan ajar yang berisi materi, metode, dan evaluasi yang dirancang secara sistematis untuk mencapai kompetensi yang diharapkan. Setianingsih (2019: 6) mengatakan unsur- unsur modul yang harus dipenuhi antara lain: (1) Judul; (2) Petunjuk belajar (petunjuk siswa); (3) Kompetensi yang akan dicapai; (4) Informasi pendukung; (5) Latihan-latihan; (6) Petunjuk kerja atau Lembar kerja; dan (7) Evaluasi. Hadits (2018: 420) mengemukakan sebuah modul bisa dikatakan menarik apabila memiliki karakteristik, seperti: (1) self instructional yaitu siswa mampu belajar mandiri berdasarkan media ajar yang digunakan; (2) self contained dimana seluruh materi dari satu unit kompetensi terdapat dalam satu media ajar secara penuh, 3) stand alone yaitu media pembelajaran dapat digunakan sendiri tanpa bergantung dengan media ajar yang lain; (4) adaptive yaitu mengikuti perkembangan ilmu dan teknologi; dan (5) user friendly yaitu setiap materi yang ada bersifat membantu penggunanya.

Penyusunan modul memiliki arti penting dalam kegiatan pembelajaran. Seperti yang diungkapkan Sipayung \& Simanjuntak (2017: 394) bahwa dengan 
menggunakan modul dalam proses belajar mengajar diharapkan nantinya: (1) siswa mampu belajar mandiri dengan atau tanpa bimbingan guru; (2) peran guru tidak mendominasi dalam kegiatan pembelajaran; (3) memadukan berbagai kecepatan belajar siswa; dan (5) siswa dapat mengukur sendiri seberapa tingkat pemahaman mereka terhadap materi yang dipelajari. Secara garis besar tujuan diadakannya pembelajaran menggunakan modul adalah membuka kesempatan bagi siswa untuk belajar menurut kecepatan dan cara masing-masing. Oleh karena itu, bisa saja di dalam pengerjaan suatu masalah yang sama, belum tentu setiap siswa menunjukkan hasil yang sama, walaupun waktu pengerjaan dimulai secara bersamaan. Pengajaran modul tersebut memberi kesempatan bagi individu untuk belajar menurut kecepatan masing-masing dalam memecahkan masalah tertentu berdasarkan latar belakang pengetahuan dan kebiasaan setiap siswa dengan cara yang bervariatif. Selain itu, penggunaan modul dirasa sangat efektif untuk mengatasi kesulitan siswa dalam belajar dikarenakan disusun secara menarik, selain itu saat proses pembelajarannya hanya membutuhkan waktu sedikit (Utami, Jatmiko, \& Suherman, 2018: 166). Namun pada kenyataannya, penggunaan modul bukan untuk mempermudah siswa dalam memahami maksud materi, melainkan sarana menghafalkan sebuah materi. Hal tersebut membuat siswa mengalami keterbatasan dalam berfikir logis dan sistematis dalam memecahkan permasalahan yang ditemukan.

Mata pelajaran yang dapat mendorong siwa untuk berfikir logis dan sistematis salah satunya adalah matematika. Menurut Niam (2020: 702) matematika berasal dari kata "mathematike" berhubungan pula dengan kata lain yang hampir sama yaitu "mathein" atau "mathenien" yang artinya ilmu pengetahuan yang didapat dengan berpikir (bernalar). Hal yang sama juga diutarakan Diantari, Gading, \& Japa (2019: 128) bahwa pembelajaran matematika pada jenjang Sekolah Dasar (SD) juga perlu memperhatikan sifat siswa yang mulai berpikir logis dan menggunakan benda-benda konkret untuk memahami konsep yang bersifat abstrak. Dapat disimpulkan bahwa guru harus menyadari, jika setiap siswa memiliki kemampuan yang berbeda dan ada beberapa siswa yang tidak menyenangi pelajaran matematika, dengan demikian guru hendaknya menyajikan pembelajaran yang aktif dan kreatif sehingga siswa merasa senang dalam belajar matematika. Dalam mata pelajaran matematika terdapat banyak sekali rumus yang harus dihafal dan kebanyakan guru tidak menjelaskan asal mula rumus tersebut.

Pembelajaran matematika yang ada belum membiasakan siswa untuk berpikir logis dan menggunakan benda konkret yang relevan dengan dunia nyata. Untuk menjembatani siswa agar terbiasa berpikir logis maka dibutuhkan pengembangan modul yang dipadukan dengan pendekatan realistik. Armita dan Hamzah (Sintawati, Berliana, \& Supriyanto, 2020: 28) mengatakan bahwa Realistik Mathematics Education (RME) merupakan pembelajaran matematika yang menggunakan hal-hal konkret atau dekat dengan kehidupan nyata sebagai titik tolak pembelajaran matematika. Sejalan dengan hal ini, Wulandari, Darma, \& Susiaty (2019: 146) menjelaskan RME merupakan pendekatan pembelajaran matematika yang menyuguhkan hal yang dekat atau nyata bagi siswa. Ide yang mendasari RME adalah pembelajaran matematika menggunakan situasi dunia nyata atau suatu konteks yang real dengan pengalaman siswa sebagai titik tolak belajar matematika. Adapun langkah-langkah pembelajaran RME menurut Shoimin 
(2014: 150-151) adalah sebagai berikut: (1) memahami masalah kontekstual, dimana guru menjelaskan soal dengan memberikan petunjuk nyata terhadap bagian-bagian tertentu yang dipahami siswa; (2) menyelesaikan masalah kontekstual dengan guru mengarahkan siswa untuk memperoleh penyelesaian soal, 3) membandingkan dan mendiskusikan jawaban; dan(4) menarik kesimpulan.

Kelebihan dari pembelajaran matematika realistik menurut Wijaya (Arniansyah, Hasyim, \& Koestoro, 2015) diantaranya adalah: (1) suasana dalam kegiatan belajar lebih menyenangkan dikarenakan menggunakan realia kehidupan dalam memecahkan masalah; (2) melatih siswa untuk terbiasa mengemukakan pendapat; dan (3) siswa akan merasa dihargai dan semakin terbuka. Sumantri (2015: 109-110) mengemukakan kelebihan dalam menggunakan RME yaitu pengetahuan yang didapat akan tertanam dalam diri siswa, dan dalam pembelajarannya tidak berorientasi hanya kepada memberikan informasi untuk memecahkan masalah saja. Berdasarkan pendapat tersebut, dapat disimpulkan bahwa dengan menggunakan RME dapat mengaitkan matematika dengan kehidupan sehari-hari dalam kegiatan belajar sehingga pengetahuan yang dibangun akan terus diingat dan berkesan untuk siswa. Karenanya pengembangan modul yang disusun harus mempunyai 3 ciri RME yang berprinsip realistik seperti yang dikemukakan oleh Ramadhanti \& Marlina (2020) prinsip dalam RME meliputi: (1) aktivitas yang membangun siswa; (2) realis (kebermaknaan); (3) pemahaman dengan menemukan informasi secara refleksi; (4) keterkaitan antar konsep; dan (5) guru membimbing siswa untuk menemukan konsep. Teori di atas dapat diringkas menjadi RME menekankan pada 3 prinsip seperti yang dikemukakan oleh Gravemeijer (Hikayat \& Suparman, 2019: 144) meliputi: (1) siswa menggunakan pengetahuan mereka sendiri dalam memecahkan masalah (2) melakukan aktivitas untuk menemukan pengetahuan bisa dengan menghubungan pengalaman siswa ataupun pemanfaatan benda-benda konkret; dan (3) setelah melakukan aktivitas dihasilkan penemuan yang dapat mengkontruksi pemahaman siswa. Selain mengaitkan dengan kehidupan nyata, siswa juga perlu memiliki kemampuan berpikir kritis dalam mempelajari matematika berupa pemecahan masalah. Kemampuan memecahkan masalah merupakan cakupan dari kemampuan berpikir tingkat tinggi atau Higher Order Thinking Skill (HOTS).

Krulik dan Rudnick (Tohir, Susanto, Hobri, Suharto, \& Dafik, 2018) menyampaikan bahwa, keterampilan berpikir terdiri dari empat tingkatan yaitu: menghafal, dasar, kritis, dan kreatif. Sejalan dengan hal ini, (Suhaesti Julianingsih, Undang Rosidin, \& Ismu Wahyudi, 2017) mengemukakan bahwa HOTS merupakan cara berpikir siswa dengan mengendalikan kemampuannya untuk menganalisis, mencipta, dan mengevaluasi semua masalah. Dapat disimpulkan bahwa aktivitas HOTS adalah proses berpikir secara kritis dan kreatif yang terjadi secara kompleks dalam diri seseorang untuk mengintrepretasikan, menganalisa, dan memanipulasi informasi guna mengetahui kebenaran sebuah informasi dalam memecahkan masalah. HOTS berbeda dengan berpikir tingkat tinggi atau Higher Order Thinking (HOT). Menurut Abidin \& Tohir (2019) perbedaan tersebut mengacu pada taksonomi Bloom yang direvisi. HOT terkait dengan kemampuan kognitif dalam menganalisis, mengevaluasi, dan mengkreasi. Sedangkan HOTS berkaitan dengan kemampuan untuk menyelesaikan permasalahan, berpikir kritis, dan kreatif. Pada 
dasarnya keterampilan berpikir tingkat tinggi mencakup kemampuan berpikir tingkat tinggi. Dikarenakan dalam berpikir kritis dan kreatif siswa juga dituntut untuk dapat menyelesaikan permasalahan dengan cara menganalisisnya terlebih dahulu.

Aktivitas HOTS melatih kemampuan siswa dalam menganalisis gagasan atau ide, merancang sebuah hipotesis, mengkonstruksi informasi yang didapatkan dengan memberikan penjelasan-penjelasan terhadap informasi tersebut guna memecahkan suatu permasalahan, dan memahami informasi yang kompleks dengan jelas. Proses berpikir secara kritis dan kreatif dengan HOTS dapat mendorong siswa untuk bisa melakukan penalaran tingkat tinggi sehingga tidak hanya terpaku pada satu pola jawaban yang dihasilkan dari proses menghafal tanpa mengetahui konsep ilmunya. Sebagian siswa belum bisa menganalisis soal, jika hal ini terus berlanjut, siswa akan mengalami kesulitan dalam menyelesaikan soal bertipe HOTS. Pemilihan menggunakan materi Volume Bangun Ruang pada pengembangan modul bukan tanpa dasar. Hal ini dilatar belakangi oleh saran dari guru kelas dan nilai yang didapat dari mengerjakan latihan soal pada materi Volume Bangun Ruang kelas V SD Negeri Sindurjan rata-rata hanya sebesar 53,71 dengan persentase siswa dibawah KKM sebanyak 81,25 \%.

Pemecahkan masalah ini membutuhkan model atau pendekatan yang dapat membantu siswa memahami konsep dalam matematika dan mendorong untuk berpikir kritis. Salah satu usaha yang dapat dilakukan guru dengan kurikulum dan kondisi siswa, yaitu dengan memperkaya keprofesionalitas-nya dengan melakukan kreasi berupa media pembelajaran yang dipadukan dengan pendekatan tertentu. Berdasarkan uraian di atas, maka perlu dikembangkan media pembelajaran matematika realistik yang terintegrasi HOTS untuk memenuhi kebutuhan siswa dalam memahami konsep matematika. Media pembelajaran yang dimaksud adalah modul. Modul juga dapat menjadi pegangan bagi guru yang berisi petunjuk dalam memfasilitasi proses pembelajaran matematika.

Penelitian yang telah dilakukan oleh Hilaliyah, Sudiana, \& Pamungkas (2019); Ismail \& Jamil (2019); dan Suastika \& Rahmawati (2019) mengenai perbedaan pengembangan modul matematika realistik dan kontekstual dengan penelitian yang lain adalah terintegrasi HOTS berupa muatan materi volume Bangun ruang. Media yang dikembangkan dalam penelitian ini memiliki ciri khas pada integrasi HOTS yang dimasukkan dalam soal atau evaluasi. Penggabungan antara realistik yang memuat tiga prinsip yaitu realistik, aktivitas, dan penemuan. Realistik atau kehidupan nyata dibuktikan dengan pengantar materi yang memuat permasalahan yang sering dijumpai oleh siswa dilengkapi dengan gambar, kegiatan berpikir siswa, serta menemukan sesuatu berupa hasil dari siswa dalam melakukan aktivitas berpikir.

\section{METODE PENELITIAN}

Metode penelitian yang digunakan adalah metode R\&D dengan menggunakan model ADDIE merupakan singkatan dari Analysis (Analisis), Design (Desain), Development (Pengembangan), Implementation (Implementasi), dan Evaluations (Evaluasi). Tahap Analysis (analisis) adalah tahap menganalisis perlunya pengembangan produk dan kelayakan syarat-syarat produk baru. Pada tahap 
analisis terbagi menjadi dua langkah yaitu analisis kurikulum dan analisis pengembangan produk. Analisis kurikulum dilakukan dengan mengkaji kurikulum 2013 yang dibuat oleh Depdiknas. Komponen yang dianalis dalam kurikulum berupa kompetensi inti, kompetensi dasar, dan indikator yang harus dicapai oleh siswa. Selanjutnya analisis pengembangan modul, dengan mengkaji aspek yang harus dipenuhi dalam sebuah modul diantaranya aspek kelayakan isi, aspek kelayakan bahasa, aspek kelayakan penyajian, dan aspek kelayakan kegrafikan. Tahap Design (Desain), adalah tahap merancang produk berdasarkan hasil analisis. adapun tahap perencanaanya diantaranya: (1) menyiapkan buku referensi yang berkaitan dengan materi; (2) penyusun peta kebutuhan modul; dan (3) menyusun desain modul. Tahap Development (Pengembangan) merupakan suatu proses merencakan desain (produk) baru menjadi kenyataan, dimana kegiatannya meliputi pembuatan dan pengujian produk yang bertujuan untuk menghasilkan produk pengembangan modul matematika setelah melalui revisi berdasarkan masukan para pakar ahli/praktisi. Selanjutnya tahap Implementation (Implementasi), yaitu penyebaran produk yang dihasilkan kepada perseorangan/ kelompok. Terakhir yaitu tahap Evaluations (Evaluasi) merupakan proses untuk mengukur keberhasilan dan kesesuaian dengan harapan pada tahap awal

Modul matematika yang dikembangkan berbasis realistik dan terintegrasi HOTS materi volume bangun ruang (kubus dan balok) kelas V SD. Subjek penelitian adalah enam siswa kelas V SD Negeri Sindurjan tahun pelajaran 2019/2020 semester genap di SD Negeri Sindurjan Purworejo. Teknik pengumpulan data dalam penelitian ini yaitu observasi, wawancara dan angket. Instrumen penelitian yang digunakan dalam pengumpulan data penelitian ini adalah angket evaluasi modul matematika dan angket respon siswa. Teknik analisis data dari hasil yang telah diperoleh menggunakan rumus sebagai berikut:

1. Validitas Produk

Tabel 1. Kriteria Validitas Produk Pengembangan

\begin{tabular}{cc}
\hline Interval Skor & Kriteria \\
\hline $\bar{x}>3,25$ & Sangat Valid \\
$2,5<\bar{x} \leq 3,25$ & Valid \\
$1,75<\bar{x} \leq 2,5$ & Kurang \\
$\bar{x} \leq 1,75$ & Kurang Valid \\
\hline
\end{tabular}

Nusaibah \& Murdiyani (2017: 478)

Produk yang dikembangkan dikatakan valid apabila tingkat kevalidan yang dicapai minimal masuk dalam kriteria valid atau mencapai kategori $>2,5$ maka produk layak untuk diuji cobakan. Apabila skor yang diperoleh kurang dari $<2,5$ maka produk harus melalui tahap revisi terlebih dahulu sebelum nantinya layak untuk diuji cobakan. 
2. Keparaktisan Produk

Tabel 2. Kriteria Kepraktisan Berdasarkan Respon Siswa

\begin{tabular}{cc}
\hline Interval & Kriteria \\
\hline $\bar{x}>3,25$ & Sangat Praktis \\
$2,5<\bar{x} \leq 3,25$ & Praktis \\
$1,75<\bar{x} \leq 2,5$ & Cukup \\
$\bar{x} \leq 1,75$ & Kurang Praktis \\
\hline
\end{tabular}

Nusaibah \& Murdiyani (2017: 478)

Kepraktisan produk diperoleh dari respon siswa melalui uji keterbacaan produk. Produk dikatakan praktis jika minimal tingkat kepraktisan yang dicapai masuk dalam kriteria praktis $>2,5$. Apabila skor yang diperoleh kurang dari $<2,5$ maka produk tidak bisa dikatakan praktis untuk nantinya layak dipergunakan.

\section{HASIL DAN PEMBAHASAN}

Penelitian pengembangan modul matematika berbasis realistik terintegrasi HOTS materi volume bangun ruang (kubus dan balok) kelas V Sekolah Dasar diuji kelayakannya melalui uji validitas oleh para ahli. Uji validitas dilakukan oleh satu dosen sebagai ahli media dan satu guru sebagai ahli materi. Pengembangan modul ini menggunakan model ADDIE yang meliputi lima tahap yaitu analysis, design, development, implementation, dan evaluation. Tahap awal yang harus dilakukan adalah analisis. Analisis dilakukan untuk memperoleh informasi terkait proses pembelajaran dan juga kebutuhan media pembelajaran matematika yang selanjutnya akan dikembangkan oleh peneliti. Pada tahap analisis dibagi menjadi dua yaitu analisis kurikulum dan analisis pengembangan modul. Tahap analisis kurikulum dilakukan dengan cara peneliti melakukan analisis terhadap kurikulum yang dipergunakan di kelas V SD Negeri Sindurjan yaitu kurikulum 2013 atau kerap disebut K-13. Dilakukan dengan mengalisis kompetensi inti dan kompetensi dasar. Sedangkan tahap analisis pengembangan modul dilakukan melalui wawancara dengan guru SD Negeri Sindurjan. Hasil wawancara menunjukkan bahwa bahan ajar yang digunakan dalam proses pembelajaran di SD Negeri Sindurjan merupakan buku yang sudah bermuatan HOTS didapat dengan membeli di percetakan, akan tetapi modul didalamnya hanya berisikan materi dan soal evaluasi yang bermuatan HOTS. Pada tahap desain dilakukan dengan membuat rancangan pengembangan bahan ajar berbasis realistik dengan penguatan HOTS. Peneliti mengembangakan modul berdasarkan desain yang telah dibuat sebelumnya yang digunakan sebagai dasar dalam pembuatan rancangan isi modul matematika. Berikut hasil produk yang dikembangkan: 


\section{Pengembangan Modul Matematika Berbasis Realistik Terintegrasi....}
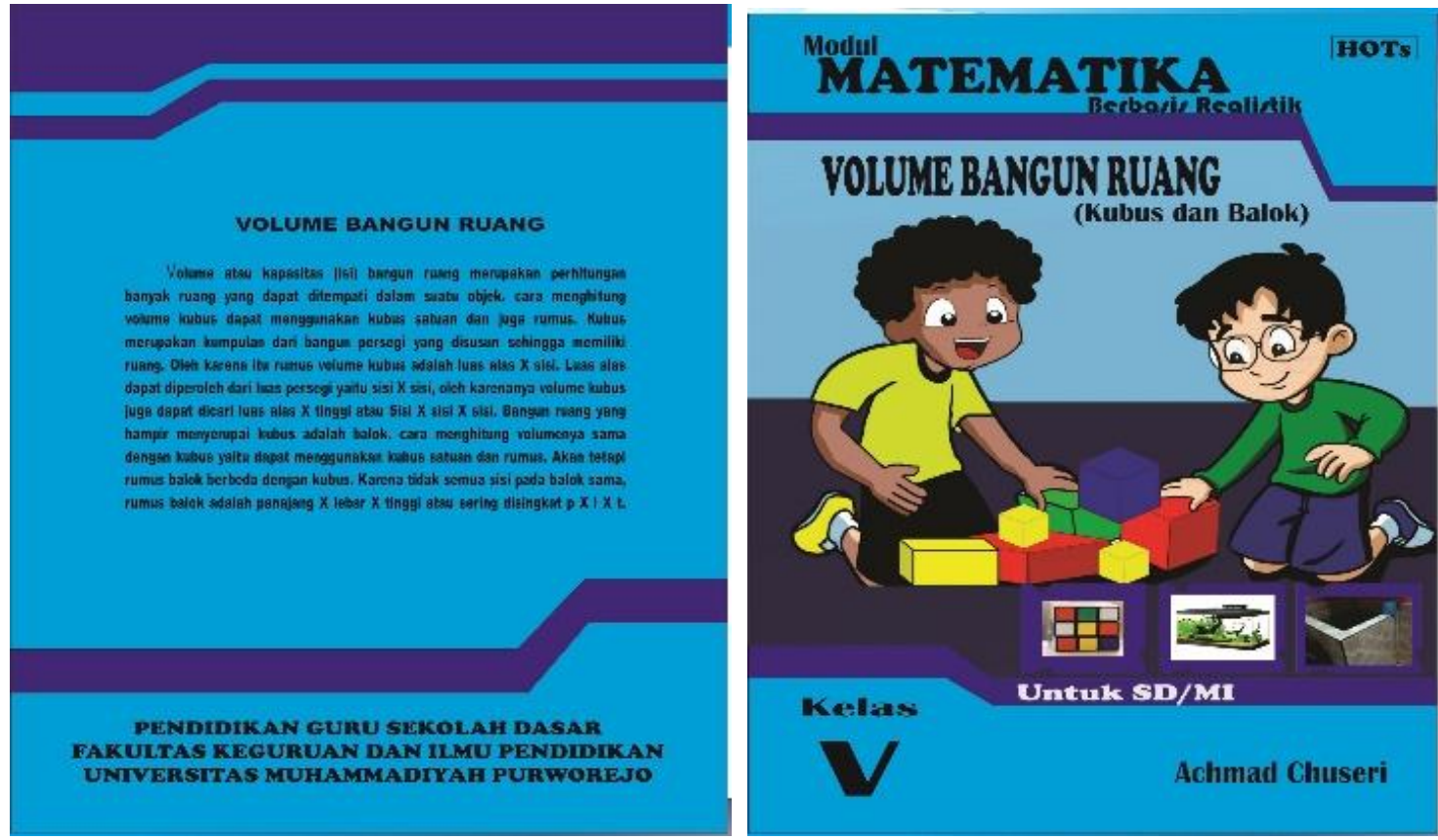

Gambar 1. Halaman depan dan belakang
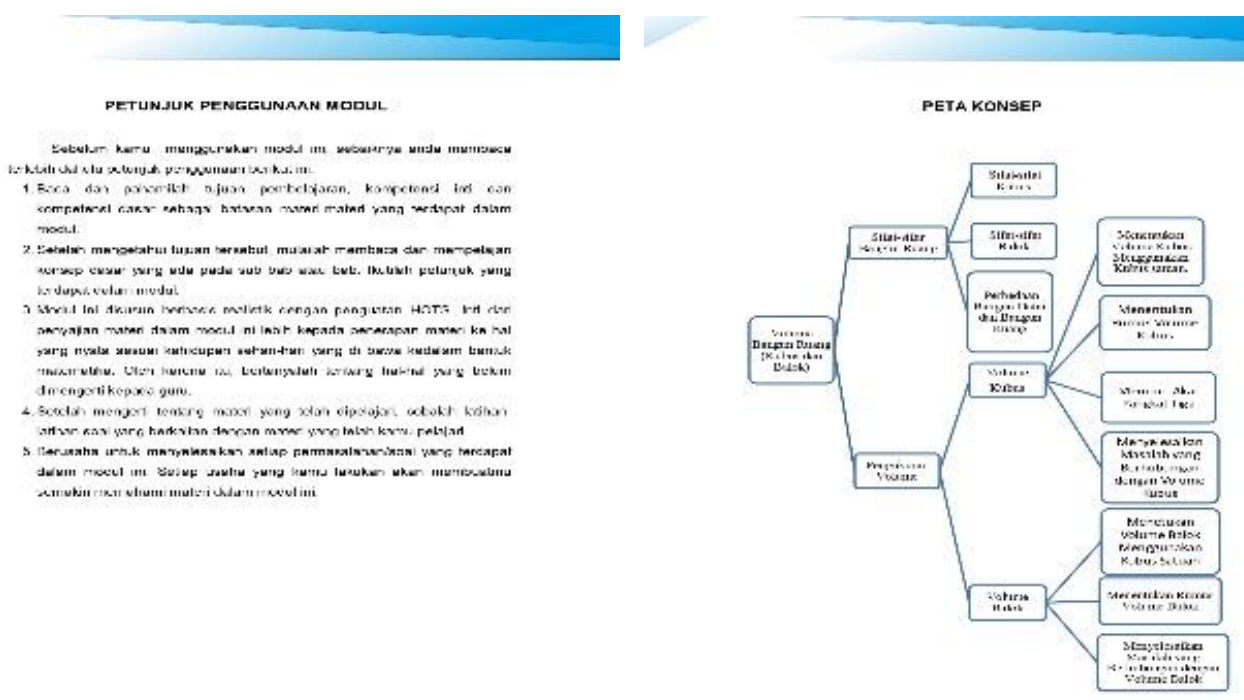

Gambar 2. Petunjuk penggunaan dan kerangka pikir 


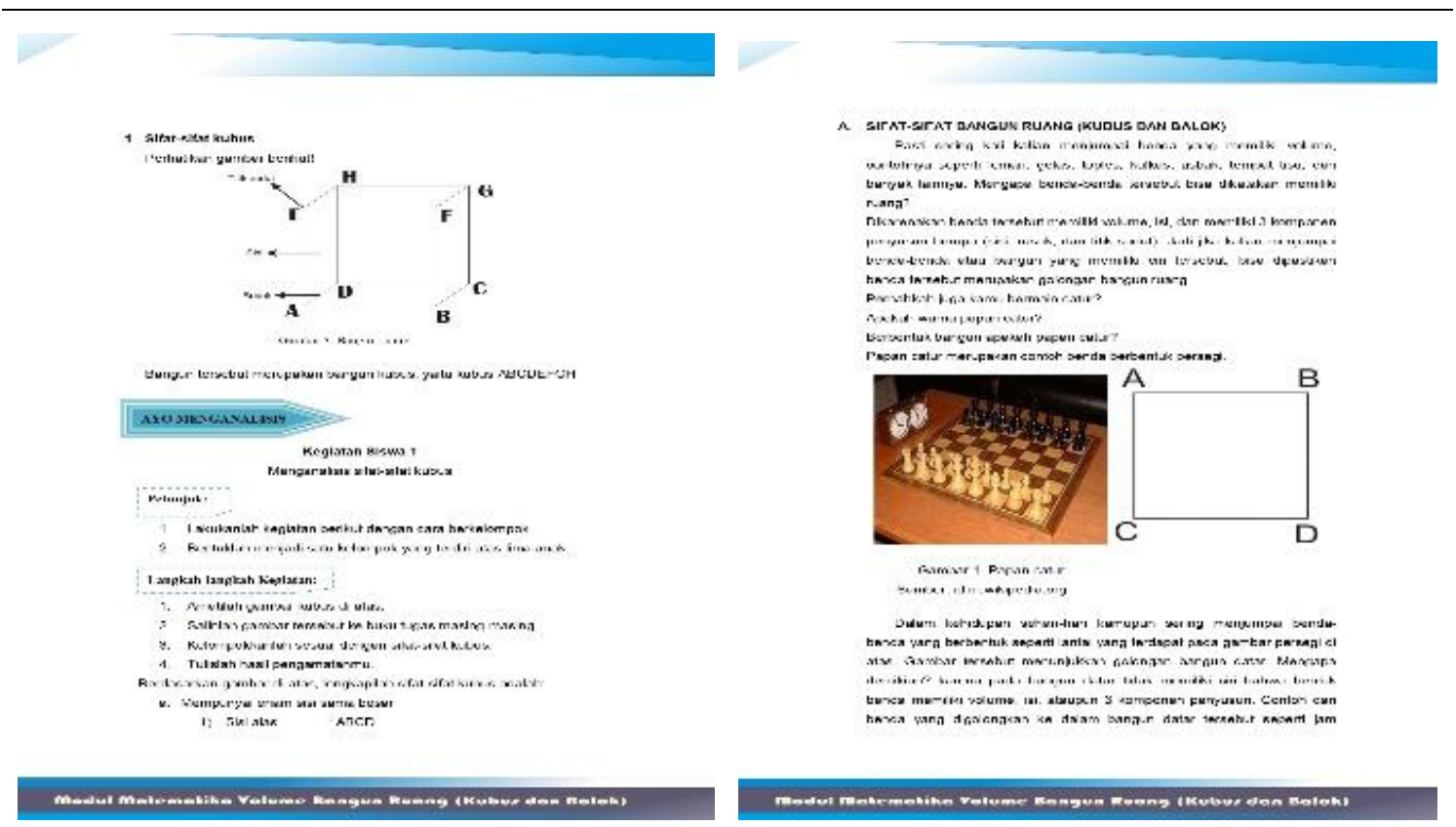

Gambar 3. Materi modul matematika realistik

Setelah selesai pada tahap pengembangan berupa merencanakan desain (produk) baru menjadi bentuk modul yang dinilai oleh ahli media dan ahli materi untuk mendapatkan saran dan motivasi terkait pengembangan media pembelajaran, selanjutnya dilakukan revisi modul matematika berdasarkan para ahli, peneliti melakukan implementasi yang dilakukan oleh peneliti melalui uji keterbacaan modul dengan berjumlah enam siswa dari SD Negeri Sindurjan kelas lima yang dipilih secara random, berdasarkan saran dari guru kelas lima yang diambil dari nilai terbaik dan terendah dan juga ijin orang tua. Ijin dari wali atau orang tua dilakukan karena kondisi pandemi Covid-19 yang mewajibkan siswa untuk belajar secara daring.

Proses pelaksanaan uji keterbacaan modul adalah dengan siswa diberikan modul dan juga angket respon siswa. Tahap terakhir adalah evaluation (Evaluasi). Pada tahap ini peneliti mengevaluasi modul matematika yang telah dikembangkan berdasarkan hasil angket yang diperoleh dari tahap pengembangan dan implementasi. Hasil validasi menunjukkan produk pengembangan modul matematika berbasis realistik terintegrasi HOTS materi volume bangun ruang (kubus dan balok) oleh dua validator dikonversikan dalam skala empat memperoleh hasil sangat valid. Modul matematika berdasarkan hasil validasi oleh ahli media memperoleh rerata sebesar 3,20. Sedangkan modul matematika berdasarkan penilaian ahli materi memperoleh rerata sebesar 3,65. Kedua hasil tersebut dikembangkan menjadi 3,40 termasuk dalam kategori sangat valid. 
Pengembangan Modul Matematika Berbasis Realistik Terintegrasi....

Tabel 3. Hasil Evaluasi Modul Matematika Realistik dari Ahli Materi

\begin{tabular}{lcc}
\hline \multicolumn{1}{c}{ Aspek Penilaian } & Skor Rata-rata & Kriteria \\
\hline Kelayakan Isi & 3,77 & Sangat Valid \\
Modul Matematika Berbasis & 3,14 & Valid \\
Realistik & 4 & Sangat Valid \\
Kelayakan Penyajian & 2,5 & Valid \\
Penguatan Kemampuan HOTS & 3,76 & Sangat Valid \\
Penilaian Bahasa & &
\end{tabular}

Berdasarkan data hasil evaluasi modul matematika realistik pada ahli materi pada Tabel 3 tersebut, menunjukkan bahwa dari Modul hasil pengembangan dalam penelitian ini sudah memuat aspek penilaian yang menjadi karakteristik suatu pembelajaran yang dianggap baik oleh ahli. Modul yang dikembangkan sudah memuat aspek kelayakan isi, modul matematika berbasis realistik, kelayakan penyajian, dan penilaian bahasa yang dinilai dengan baik untuk menentukan kualitas modul. Tergolong dalam modul yang layak digunakan diukur melalui kevalidan dan juga kepraktisan.

Aspek yang divalidasikan ada 5 yaitu kelayakan isi, penilaian modul matematika berbasis realistik diperoleh rerata sebesar 3,77, modul matematika berbasis realistik diperoleh rerata sebesar 3,14, kelayakan penyajian diperoleh rerata sebesar 4, penguatan kemampuan HOTS diperoleh rerata sebesar 2,5 dan penilaian bahasa diperoleh rerata sebesar 3,76 . Skor penilaian sesuai dengan tabel 1 klasifikasi penilaian skala empat lembar validasi. Berdasarkan diagram di atas dapat disimpulkan penilaian ahli media memperoleh rerata sebesar 3,20. Sedangkan ahli materi memperoleh rerata sebesar 3.65. Jadi, jika di rata-rata hasil kedua validasi tersebut memperoleh skor 3,40 yang artinya produk pengembangan modul matematika sangat valid.

Lembar angket respon siswa sebanyak enam subyek secara keseluruhan diperoleh skor rerata sebanyak 3,40 berkategori sangat praktis dan memenuhi syarat kelayakan untuk sebuah modul pembelajaran. Aspek yang dinilai ada 3 meliputi tampilan, penyajian materi, dan manfaat.

Tabel 4. Hasil Penilaian modul matematika berbasis realistik oleh siswa

\begin{tabular}{ccc}
\hline Aspek Penilaian & Skor Rata-rata & Kriteria \\
\hline Tampilan & 3,36 & Sangat Praktis \\
Penyajian Materi & 3,38 & Sangat Praktis \\
Manfaat & 3,47 & Sangat Praktis \\
\hline
\end{tabular}

Berdasarkan data hasil respon siswa pada Tabel 4 tersebut, menunjukkan bahwa dari 6 subyek diperoleh rata-rata keseluruhan memperoleh nilai 3,40 dengan kategori praktis dan memenuhi syarat kelayakan untuk sebuah modul 
pembelajaran. Aspek yang dinilai meliputi tampilan memperoleh skor rerata sebesar 3,35 dengan kriteria sangat praktis, kemudian penyajian materi mendapatkan skor rerata sebesar 3,38 dengan kriteria sangat praktis, dan terakhir pada penilaian aspek manfaat mendapatkan skor rerata sebesar 3,47 dengan kriteria sangat praktis. Berdasarkan hasil ketiga penilaian aspek pada modul matematika berbasis realistik oleh siswa diperoleh skor rata-rata 3,4 atau $>3,25$ tergolong dalam kriteria sangat praktis dan memenuhi syarat kelayakan untuk sebuah modul pembelajaran. Sejalan dengan hal ini, Khoeriyah (Faradina \& Mukhlis, 2020) mengemukakan bahwa hasil modul matematika dengan berbasis pendekatan Pendidikan Matematika Realistik Indonesia (PMRI) memiliki efek potensial terhadap hasil belajar siswa dimana menunjukkan kemajuan yang sangat baik. Selain itu, dengan mengembangkan modul berbasis pendekatan realistik dapat membantu kesulitan siswa dalam memahami materi tersebut. Penelitian ini berdasarkan pada permasalahan yang terjadi bahwa belum adanya modul yang digunakan dengan pendekatan tertentu terintegrasi HOTS. Pembelajaran yang dilakukan belum optimal untuk menunjang kemampuan HOTS serta cara berkomunikasi matematika siswa dikarenakan proses pembelajarannya belum melibatkan siswa secara langsung dalam memahami materi yang dipelajari.

Penyajian materi berupa persoalan yang dekat dengan kehidupan siswa, kemudian pembahasannya menggunakan hal-hal konkret berupa aktivitas untuk menjembatani siswa dalam memahami konsep, serta mendesain modul agar siswa mampu menarik konsep berdasarkan apa yang mereka pahami. Pernyataan tersebut didukung oleh teori yang diungkapkan oleh Zaini (2014: 128) bahwa teori belajar Skinner lebih menekankan pada tingkah laku manusia, dimana dalam belajar pengetahuan yang didapat bisa terbentuk melalui stimulus yang akan memiliki respon apabila adanya penguatan. Selaras yang diutarakan Memolo (2019: 472) terdapat keterkaitan antara respon dengan stimulus, bahwa respon dapat diperkuat dengan adanya penguatan. Respon akan menguat apabila stimulus yang diberikan juga semakin kuat. Jadi dapat disimpulkan bahwa dengan penggunaan media pembelajaran dapat menguatkan stimulus siswa untuk berpikir logis dengan perantara realia sehingga respon siswa dapat meningkat.

\section{KESIMPULAN}

Berdasarkan penelitian pengembangan modul matematika berbasis realistik terintegrasi HOTS materi volume bangun ruang (kubus dan balok) kelas V SD diperoleh kesimpulan sebagai berikut: Hasil akhir berupa pengembangan modul matematika berbasis realistik terintegrasi HOTS materi volume bangun ruang (kubus dan balok) kelas V Sekolah Dasar. Modul matematika berbasis realistik terintegrasi HOTS yang telah dikembangkan memenuhi kelayakan dengan kriteria valid dan praktis.

Kevalidan produk dinilai oleh dua validator yaitu ahli media dan ahli materi. Penilaian ahli media terhadap modul yang telah dikembangkan rata-rata sebesar 3,20 dan penilaian oleh ahli materi terhadap modul yang telah dikembangkan ratarata sebesar 3,65. Dari kedua hasil penilaian terhadap modul matematika berbasis realistik terintegrasi HOTS pada kelas V SD mendapatkan nilai sebesar 3,40 dengan kategori sangat valid sehingga layak digunakan dalam pembelajaran. Respon siswa 
terhadap penilaian produk memperoleh rerata 3,40 yang termasuk dalam kriteria sangat praktis. Berdasarkan aspek kevalidan dan kepraktisan modul memperoleh nilai > 2,5 maka modul memenuhi syarat kelayakan untuk sebuah modul. Media pembelajaran berupa modul matematika berbasis realistik ini dapat dimanfaatkan dalam proses pembelajaran matematika kelas V SD untuk melatih siswa lebih mandiri dalam belajar matematika. Selain itu juga dapat dimanfaatkan sebagai pegangan siswa dalam belajar secara individu atau mandiri.

\section{DAFTAR PUSTAKA}

Abidin, Z., \& Tohir, M. (2019). Keterampilan Berpikir Tingkat Tinggi dalam Memecahkan Deret Aritmatika Dua Dimensi Berdasarkan Taksonomi Bloom. Alifmatika: Jurnal Pendidikan Dan Pembelajaran Matematika, 1(1), 44-60. https://doi.org/10.35316/alifmatika.2019.v1i1.44-60

Arniansyah, M., Hasyim, A., \& Koestoro, B. (2015). Peningkatan Hasil Belajar melalui Model Pembelajaran Realistic Mathematic Education. Jurnal Teknologi Informasi Komunikasi Pendidikan (Old), 3(1), 1-10.

Diantari, N. L. G. A., Gading, I. K., \& Japa, I. G. N. (2019). Pengaruh Model Pembelajaran Missouri Mathematics Project Realistik Berbantuan Lks Terhadap Hasil Belajar Matematika. Jurnal Imiah Pendidikan Dan Pembelajaran, 3(2), 127-136.

Faradina, A., \& Mukhlis, M. (2020). Analisis Berpikir Logis Siswa dalam Menyelesaikan Matematika Realistik Ditinjau dari Kecerdasan Interpersonal. Alifmatika: Jurnal Pendidikan Dan Pembelajaran Matematika, 2(2), 129-151. https://doi.org/10.35316/alifmatika.2020.v2i2.129-151

Hikayat, C., \& Suparman, S. (2019). Analisis Kebutuhan E-Modul Berpendekatan Realistic Mathematics Education untuk Meningkatkan Kemampuan Berpikir Kritis. Prosiding Sendika, 5(1), 143-146.

Hilaliyah, N., Sudiana, R., \& Pamungkas, A. S. (2019). Pengembangan Modul Realistic Mathematics Education Bernilai Budaya Banten untuk Mengembangkan Kemampuan Literasi Matematis Siswa. Jurnal Didaktik Matematika, 6(2), 121-135.

Ismail, A. D., \& Jamil, A. F. (2019). Pengembangan Modul Berbasis Matematika Realistik Bercirikan Budaya Indonesia. Kalamatika: Jurnal Pendidikan Matematika, 4(2), 177-192.

Istikomah, I., \& Purwoko, R. Y. (2020). Sigil: Pengembangan E-Modul Berbasis Realistik pada Materi Lingkaran Untuk Siswa Kelas VIII SMP. JP3M (Jurnal Penelitian Pendidikan Dan Pengajaran Matematika), 6(2), 91-98.

Memolo, T. (2019). Pengembangan Komik Digital Berbantuan QR Code Materi Rata-Rata untuk Meningkatkan Literasi Matematika. Seminar Nasional Edusainstek, 3(1), 470-481.

Niam, S. (2020). Pengaruh Kombinasi Metode Pembelajaran Gasing dan Realistic Mathematics Education (RME) Terhadap Prestasi Belajar Matematika PADA 
Siswa SDN 2 Sekuro Jepara. Prosiding Konferensi Ilmiah Mahasiswa Unissula (KIMU) Klaster Humanoira.

Nusaibah, N., \& Murdiyani, N. M. (2017). Pengembangan Perangkat Pembelajaran dengan Pendekatan Pendidikan Matematika Realistik Indonesia pada Materi Lingkaran untuk Siswa Kelas VII SMP. Seminar Matematika Dan Pendidikan Matematika, 475-482.

Rahayu, G. D. S., \& Firmansyah, D. (2019). Pengembangan pembelajaran inovatif berbasis pendampingan bagi guru sekolah dasar. Abdimas Siliwangi, 1(1), 1725.

Ramadani, Z., \& Oktiningrum, W. (2020). Pengembangan Media Pembelajaran Matematika "Minitim Kabar" untuk Meningkatkan Hasil Belajar Kognitif Siswa. Alifmatika: Jurnal Pendidikan Dan Pembelajaran Matematika, 2(2), 152168. https://doi.org/10.35316/alifmatika.2020.v2i2.152-168

Ramadhanti, E., \& Marlina, R. (2020). Pembelajaran Realistic Mathematics Education (RME) Terhadap Kemampuan Pemahaman Matematis. Prosiding Seminar Nasional Matematika Dan Pendidikan Matematika, 2(1), 876-882.

Rokhim, A. R., Suparmi, S., \& Prayitno, B. A. (2018). Pengembangan Modul IPA Berbasis Problem Based Learning pada Materi Kalor dan Perpindahan untuk Meningkatkan Kemampuan Berpikir Kritis Siswa SMP Kelas VII. INKUIRI: Jurnal Pendidikan IPA, 7(1), 143-150.

Rusmana, I. M., \& Kurniawarsih, M. (2020). Pengembangan Media Pembelajaran Komik Matematika Siswa Kelas IV Sekolah Dasar Berbasis Budaya. Jurnal Lebesgue: Jurnal Ilmiah Pendidikan Matematika, Matematika Dan Statistika, 1(1), 39-48.

Setianingsih, S. (2019). Pengembangan Modul Berbasis Edutainment pada Pokok Bahasan Bangun Datar. UIN Raden Intan Lampung.

Shoimin, A. (2014). Model Pembelajaran Inovatif dalam Kurikulum 2013. Yogyakarta: Ar-ruzz media.

Sintawati, M., Berliana, L., \& Supriyanto, S. (2020). Real Mathematics Education (RME) untuk Meningkatkan Hasil Belajar dan Kemampuan Pemecahan Masalah Matematika Siswa Sekolah Dasar. PeTeKa, 3(1), 26-33.

Sipayung, T. N., \& Simanjuntak, S. D. (2017). Efektivitas Pembelajaran Kooperatif Dengan Menggunakan Modul. AKSIOMA: Jurnal Program Studi Pendidikan Matematika, 6(3), 393-398.

Suastika, I. K., \& Rahmawati, A. (2019). Pengembangan Modul Pembelajaran Matematika dengan Pendekatan Kontekstual. Jurnal Pendidikan Matematika Indonesia, 4(2), 58-61.

Suhaesti Julianingsih, S. J., Undang Rosidin, U. R., \& Ismu Wahyudi, I. W. (2017). Pengembangan Instrumen Asesmen HOTS untuk Mengukur Dimensi Pengetahuan IPA Siswa di SMP. Jurnal Pembelajaran Fisika, 5(3), 59-68.

Sumantri, M. S. (2015). Strategi Pembelajaran Teori dan Praktik di Tingkat Pendidikan Dasar. Jakarta: Rajawali Pers. 
Tohir, M., Susanto, Hobri, Suharto, \& Dafik. (2018). Students' Creative Thinking Skills in Solving Mathematics Olympiad Problems Based on Problem-Solving Polya and Krulik-Rudnick Model. Advanced Science Letters, 24(11), 83618364. https://doi.org/10.1166/asl.2018.12563

Utami, T. N., Jatmiko, A., \& Suherman, S. (2018). Pengembangan Modul Matematika dengan Pendekatan Science, Technology, Engineering, And Mathematics (STEM) pada Materi Segiempat. Desimal: Jurnal Matematika, 1(2), 165-172.

Widyautama, T. R. P. (2003). Undang-Undang RI Nomor 20 Tahun 2003 tentang Sistem Pendidikan Nasional. Yogyakarta: Pustaka Widyatama.

Wulandari, S., Darma, Y., \& Susiaty, U. D. (2019). Pengembangan Modul Berbasis Pendekatan Realistic Mathematics Education (RME) Terhadap Pemahaman Konsep. Jurnal Pendidikan Informatika Dan Sains, 8(1), 143-152.

Zaini, R. (2014). Studi Atas Pemikiran BF Skinner Tentang Belajar. Terampil: Jurnal Pendidikan Dan Pembelajaran Dasar, 1(1), 118-129. 